\title{
Ajan lyhyt historia
}

Stephen W. Hawking, Ajan lyhyt historia. Alkuräjähdyksestä mustiin aukkoihin. WSOY, Helsinki 1988, $193 \mathrm{~s}$.

Tieteen popularisointi on vaikeana pidettyä puuhaa - niin vaikeana, että harvat uskaltavat siihen ryhtyä ja vielä harvemmat siinä onnistuvat. Popularisoijia on muutamia ja näiden joukossa omat aatelisensa. Meillä Suomessa ehkä Anto Leikola ja kansainvälisessä kirjallisuudessa vaikka juuri Stephen W. Hawking.

Stephen W. Hawkingin kirja ilmestyi jokin aika sitten suomeksi ja siitä on kirjoitettu jo useitakin, pääasiassa ylistäviä arvioita. Yhdyn moniin ylistyksiin, enkä pyri arvioimaan tekstiä fyysikkona tai tähtitieteilijänä. Kiinnostukseni koskee sitä, miten Hawking popularisoi teemaansa.

Hawking kysyy: Onko ajalla alku? Loppuuko aika joskus? Onko maailmankaikkeus ääretön? Onko maailmankaikkeudella reunat? Näihin kysymyksiin voidaan ajatella löytyvän vastauksia teoreettisesta fysiikasta. Mutta Hawkingin intressinä on pohtia myös onko Jumala olemassa? Tämä ongelma ei ratkeakaan enää puhtaan tieteen piirissä, vaan on luonteeltaan laajempi: sekä filosofinen että maailmankatsomuksellinen.

Hawking tarkastelee aluksi Galilein ja Newtonin ajatusmaailmoja. Tämän jälkeen tarkastelu siirtyy askel askeleelta yleisen suhteellisuusteorian kautta kvanttifysiikkaan. Lopulta Hawking hahmottelee teoriaa, joka yhdistäisi nämä kaksi. Tällöin olisi yksi teoria, joka yhdistää maailmankaikkeuden sen suurimmasta yleisestä tarkastelusta pienimpään ilmiöönsä. Varsinainen teksti käsittää 11 lukua. Näiden lisäksi Hawking on kirjoittanut koime näkökulmaa merkittäviin edeltäjiinsä: Albert Einsteiniin, Galileo Galileihin, Isaac Newtoniin. Katsaukset ovat suppeita, vain muutaman sivun kukin, mutta heijastavat Hawkingin tietoisuutta traditiosta, jonka jatkaja hän on.
Kirjassa on lisäksi sanasto ja hakemisto; ne helpottavat kirjan lukijaa ja antavat kirjan käytölle ikää: kertalukemisen sijasta kirjaan ja sen käsittelemiin ongelmiin on helppo palata muissakin yhteyksissä.

Hawkingin teema ei ole kaikilta osin aivan vieras suurelle yleisölle - esimerkiksi teoria mustista aukoista on puhkaissut "uutiskynnyksen" ja murtautunut jossakin mielessä lähes koko kansan tietoisuuteen, usein puoliksi mystifioidussa muodossa. Hawkingin kirjasta selviää, että mustat aukot eivät olekaan mustia, vaan ne säteilevät kymmenen megawatin teholla ja ovat siten pikemminkin valkohehkuisia. Hawking selvittää myös miten kävisi astronautille, joka putoaa mustaan aukkoon (mutta tämän tietämisen iloa en halua viedä kirjan lukijalta).

Fysiikan ongelmat ovat vaikeita ratkaistavaksi, mutta onko helpompaa välittää tieteellistä tietoa siten, että sen voi maallikkokin ymmärtää ja samalla välttää mystifioinnin ja yksinkertaistuksen vaarat? Hawking käyttää ainakin seuraavia keinoja: hän selvittää asiat yksinkertaisesti mutta yksinkertaistamatta; tuo teeman lähemmäs kertomalla keventäviä juttuja itsestään ja muista fyysikoista silti sortumatta häiritsevään jutusteluun ja loputa esittämällä sattuvia ja havainnollistavia mielikuvia ja analogioita. Kirjassa on useita kuvia ja kuvioita, jotka visualisoivat näitä mielikuvia.

Kirjan suosion voikin ymmärtää juuri tältä kannalta. Hawking on onnistunut tekemään vaikean aiheen sellaiseksi, että maallikko tuntee siinä olevan jotain tuttua ja kokee oivaltavansa siitä jotain Näin osa siitä neroudesta, jonka on sanottu olevan Hawkingin aivoissa, valaisee myös lukijaa. Lukija tuntee olevansa osa suurta viisautta. Kun Hawkingin hahmo lisäksi muutoin herättää sympatiaa, kaikki edellytykset kirjan sanoman vastaanotolle ovat olemassa. Hawking sairastaa amyotrooppista lateraaliskleroosia (ALS), joka on eräs liikehermoja jäytävä sairaus, mutta on sairaudestaan huolimatta onnistunut "lähes kaikessa muussa" - kuten hän itse kirjassa toteaa. Tällä hetkellä hän on Lucasin professori Cambridgen yliopistossa. Samaa virkaa ovat aiemmin hoitaneet maineikkaat Isaac Newton ja P.A.M. Dirac. Ensinmainittu tutki maailmankaikkeuden suuria mittoja, viimemainittu pieniä. Hawkingin kunnianhimoinen tavoite on tutkia pieniä ja suuria mittoja ja yhdistää niitä koskevat nykyiset teoriat yhtenäisiksi. Hawkingin mukaan on kolme mahdollisuutta:

1. On olemassa täydellinen yhtenäisteoria, jonka joskus löydämme, jos olemme riittävän nokkelia.

2. Ei ole olemassa maailmankaikkeutta koskevaa perimmäistä teoriaa, vaan pelkästään loputon sarja teorioita, jotka kuvaavat maailmankaikkeutta toinen toistaan tarkemmin.

3. Ei ole mitään maailmankaikkeutta koskevaa teoriaa: ilmiöt voidaan ennustaa jollain tarkkuudella, mutta perimmältään tapahtumat ovat sattumanvaraisia ja mielivaltaisia.

Kaikki tähänastinen kokemus ja valtaosa nykyisestä tieteenfilosofiastakin tuntuu päätyvän toisen vaihtoehdon mukaiseen tulokseen. Tästä huolimatta on kiehtovaa ajatella ensimmäisen vaihtoehdon toteutumista. Hawkingin mielestä se olisi kuitenkin vielä välivaihe. Vaikka meillä olisi yhtenäisteoria, siitä ei vielä automaattisesti seuraisi sitä, että ymmärtäisimme ihmisen käyttäytymistä. Ja Hawking ei ole tavoitteen asettelussa vaatimaton: lopullinen päämäärä on tapahtumien - ja oman olemassaolomme - täydellinen ymmärtäminen. Toistaiseksi yhtenäisteoriaa ei ole onnistuttu löytämään, mutta Hawking uskoo lujasti näin vielä käyvän. 
Hawkingin kirjassa on tärkeää myös sen maailmankatsomuksellinen puoli. Hawkingille Jumala on mitä kiinnostavin pohdinnan kohde, vaikka hän onkin tullut siihen johtopäätökseen, ettei Jumalaa ehkä ole olemassa. Jumala onkin siitä erikoinen "olento", että vaikka hän (?) ei missään järjellisessä merkityksessä olisikaan olemassa, niin kielellisenä fenomeenina "Jumala" edustaa jotakin, jota on pohdittu varsin paljon.

Jos kykenisin muistamaan ulkoa joka sanan Hawkingin kirjasta, aivoihini olisi tallentunut noin kaksi miljoonaa tiedonpalasta eli aivojeni sisäinen järjestys olisi kasvanut noin kahdella miljoonalla yksiköllä. Samalla olisin kuitenkin muuttanut ainakin tuhat kilokaloria ruuassa saatua järjestynyttä energiaa lämmön epäjärjestyneeksi energiaksi, joka on siirtynyt ympäristööni ilmavirtausten mukana tai hikoiluna. Lämmöksi muuttuminen on lisännyt maailmankaikkeuden epäjärjestystä arviolta 20 miljoonaa miljardia miljardia yksikköä eli noin 10000 miljoonaa miljardia kertaa enemmän kuin aivojeni järjestys olisi kasvanut. Ja koska ehtona on,e ttä muistaisin kaiken Hawkingin kirjasta, tilanne järjestyksen rakentajalle on toivoton: järjestynyttä energiaa kuluu epäjärjestyksen synnyttämiseen aina enemmän kuin mitä järjestystä syntyy. Toisaalta lohdullista on, että tämä epäjärjestys syntyy joka tapauksessa - on siis mielekästä luoda järjestystä epäjärjestykseen.

Hawkingissa yhdistyy asiantuntevuus, sympaattisuus, havainnollisuus, laaja-alaisuus ja eksoottisuus (suhteessa suureen osaan lukijoita). Näistä ehkä vain sympaattisuus on ominaisuus, jota on vaikea hallita. Muut ovat asiantuntevuuden ja harjoituksen tulosta.

Risto Vartevan käännös on sujuva ja vaikuttaa asiantuntevalta. Kansilieve suosittelee kirjaa "niille, jotka haluavat perehtyä nykyajan kosmologiaan ilman monimutkaisia matemaattisia yhtälöitä." Mutta yhtä hyvin kirjaa voi suositella niille, jotka ovat kiinnostuneet koulutuksessa ja kasvatuksessa tieteen popularisoinnista.

Pekka Kalli 